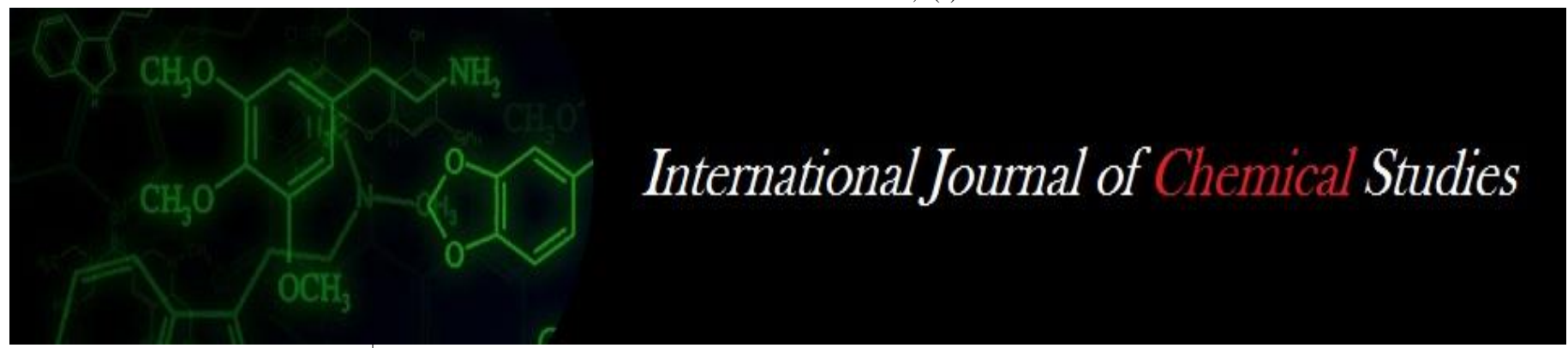

P-ISSN: 2349-8528

E-ISSN: 2321-4902

www.chemijournal.com

IJCS 2020; 8(4): 2630-2634

(C) 2020 IJCS

Received: 07-05-2020

Accepted: 09-06-2020

\section{R Jeyasrinivas}

Agricultural Research Station,

Paramakudi, Tamil Nadu, India

\section{S Sakthivel}

Agricultural Research Station,

Paramakudi, Tamil Nadu, India

\section{P Yogameenakshi}

Agricultural Research Station,

Paramakudi, Tamil Nadu, India
Corresponding Author:

R Jeyasrinivas

Agricultural Research Station,

Paramakudi, Tamil Nadu, India

\section{Evaluation of split application of nitrogen and potassium on semi-dry rice cultivation in Ramanathapuram, Tamil Nadu}

\author{
R Jeyasrinivas, S Sakthivel and P Yogameenakshi
}

DOI: $\underline{\text { https://doi.org/10.22271/chemi.2020.v8.i4ae.10031 }}$

\begin{abstract}
A field experiment was conducted during rainy (Rabi) season during 2014, 2015 and 2016 at Agricultural Research station, Paramakudi to evaluate the split application of nitrogen and potassium in semi-dry rice cultivation in Ramanathapuram district. The experiment was laid out in split plot design with three replications with Anna(R) 4, ADT 45 and Norungan local varieties. The sub plot consists five levels nutrients; the results revealed that the short duration rice variety Anna (R) 4 is suitable for semi-dry rice cultivation $\left(2298 \mathrm{~kg} \mathrm{ha}^{-1}\right)$ under drought conditions of Ramanathapuram district. Application of entire dose of $\mathrm{P}$ with $1 / 4^{\text {th }}$ dose of $\mathrm{N}$ and $1 / 4^{\text {th }}$ dose of $\mathrm{K}$ as basal application and remaining dose of $\mathrm{N}$ and $\mathrm{K}$ in three splits on vegetative, active tillering and panicle initiation stages recorded the good performance of plant growth $(83.5 \mathrm{~cm})$ and yield attributes viz., productive tillers $/ \mathrm{m}^{2}(147.1)$ and grains/ panicle (118.8). It will ultimately increase the grain yield $\left(2652 \mathrm{~kg} \mathrm{ha}^{-1}\right)$ in semi-dry rice cultivation.
\end{abstract}

Keywords: Semi-dry rice cultivation, varieties, nitrogen and potassium

\section{Introduction}

Rice (Oryza sativa.) is an important food crop of the world. It is stable food of the people of South East Asia and more than half of the world population subsists on this crop. India has to produce about 125 million tonnes of rice by 2025 to feed the ever growing population. Rice crop is grown by many ways depending upon resource availability mainly due to resource constraints, especially water and labour, direct seeding under dry condition is now emerging as new trend in rice cultivation. In India, particularly Tamil Nadu is having some area under rainfed and semi-dry rice and has a vast scope of growing rice under aerobic conditions. The semi-dry rice is a contingent plan to command areas, anticipating the release of water in rice crop can be established under rainfed conditions up to maximum of 45 days as that of previous two situations. Field is converted on wet condition on receipt of canal water and nutrient management is decided according to the period of irrigation (Bouman \& Lampayan 2009) ${ }^{[3]}$. The new concept of aerobic rice entails the use of nutrient responsive different cultivars that are initially adapted to aerobic environment aiming at yields of 70-80\% of high (Kumar \& latha 2011) ${ }^{[7]}$. Semi dry rice cultivation refers to rice which is sown on dry seed bed as an upland crop taking advantage of monsoon rains. At $4^{\text {th }}$ and $5^{\text {th }}$ leaf stage, when the rainfall intensifies or sufficient water is released from the tank or irrigation projects, the field is converted into wetland rice. Nitrogen and potassium are the key nutrients which frequently limit the rice production. In puddle rice ecosystem, the nitrogen use efficiency is approximately $30 \%$ where as in upland rice, whether irrigated or rainfed, nitrogen use efficiency would be in the range of 40 to $60 \%$ Split application is one of the important strategies for efficient use of nitrogen fertilizers throughout the growing season by synchronizing with plant demand, reducing denitrifaction losses and improved $\mathrm{N}$ uptake for maximum grain yield in semi-dry rice. Nitrogen requirement of semi-dry rice at different stages is also differ from transplanted one. Nitrogen and potassium application should coincide with crop growth and its requirement. However, there is a need to quantify the nitrogen and potassium dose at different growth stages of semi-dry rice with particular reference to the cultivars, location and management conditions. Nitrogen and potassium is the main nutrients that determines rice yield, due to its role in the photosynthesis, biomass accumulation and, 
spikelet formation (Hasegawa et al. 1994: Yoshida et al. 2006) ${ }^{[6,16]}$. Many factors are responsible for increasing yield and quality of crops. Among these, proper and balanced application of fertilizers is one of the most important factor contributing towards higher productivity (Ahamed 1994) ${ }^{[1]}$. In addition, altering the split doses of nitrogen and potassium requirement is also a need to analyze under semi-dry rice condition. Therefore, the optimization of nitrogen and potassium levels as well as split doses to different crop growth stages is more important to produce higher grain yield under semi-dry rice eco system. Hence, the experiment was conducted to study the evaluation of split application of nitrogen and potassium in semi-dry rice cultivars in Ramanathapuram district.

\section{Materials and methods}

The experiment was conducted during the rainy season 2013, 2014 and 2015 at Agricultural Research station, Paramakudi. The Paramakudi is located in southern region of Ramanathapuram district. The soil of the experimental field is clayey loam. The chemical analysis of soil showed saline condition, $\mathrm{pH}$ is 8.5 , low in organic carbon (0.35), available nitrogen $\left(140 \mathrm{~kg} \mathrm{ha}^{-1}\right)$, available phosphorus $\left(17 \mathrm{~kg} \mathrm{ha}^{-1}\right)$ and available potassium $\left(290 \mathrm{~kg} \mathrm{ha}^{-1}\right)$. The experiment was laid out in split plot design with three replications. The main plot consists of three different rice varieties viz., Anna (R) 4, ADT 45 and Norungan local variety. The sub plot consists five levels nutrient viz., Basal application of recommended dose of NPK (75:25:37.5 $\left.\mathrm{kg} \mathrm{ha}^{-1}\right)\left(\mathrm{N}_{1}\right)$, Full dose of recommended dose of $\mathrm{P}$ with $1 / 2^{\text {th }}$ dose of $\mathrm{K}$ as basal and remaining dose of $\mathrm{N}$ and balance dose of $\mathrm{K}$ as top dressing of 2 splits in vegetative (25 days after sowing (DAS) and active tillering (45 DAS) stages $\left(\mathrm{N}_{2}\right)$, Full dose of $\mathrm{P}$ with half the dose of $\mathrm{K}$ with $1 / 3^{\text {rd }}$ dose of $\mathrm{N}$ as basal and top dressing of $2 / 3^{\text {rd }}$ dose of $\mathrm{N}$ and half the dose of $\mathrm{K}$ in 2 splits in vegetative (25 DAS) and active tillering (45 DAS) stages $\left(\mathrm{N}_{3}\right)$, Full dose of $\mathrm{P}$ with half the dose of $\mathrm{K}$ and $1 / 4^{\text {th }}$ dose of $\mathrm{N}$ as basal and $3 / 4^{\text {th }}$ dose of $\mathrm{N}$ and half the dose of $\mathrm{K}$ in 3 splits in vegetative (25DAS) and active tillering (45 DAS) and panicle initiation (65 DAS) stages $\left(\mathrm{N}_{4}\right)$, Entire dose of $\mathrm{P}$ with $1 / 4^{\text {th }}$ dose of $\mathrm{N}$ and $1 / 4^{\text {th }}$ dose of $\mathrm{K}$ as basal application and remaining dose of $\mathrm{N}$ and $\mathrm{K}$ in three splits during vegetative (25 DAS) and active tillering (45 DAS) and panicle initiation (65 DAS) stages $\left(\mathrm{N}_{5}\right)$. The rainfall data showed that a total of $372 \mathrm{~mm}$ rainfall was received in 18 rainy days from $21^{\text {st }}$ September in 2012 to harvesting stage, $206 \mathrm{~mm}$ of rainfall received in 20 rainy days from $18^{\text {th }}$ September 2013 to harvesting stage and $484 \mathrm{~mm}$ of rainfall received in 31 rainy days from $26^{\text {th }}$ September 2014 to harvesting stage. No pest and disease occurred during the crop growth periods. The data on different observations were statistically analyzed as per Panse and Sukatme method (1967) ${ }^{[8]}$. The crop was harvested when plants turned yellow and attained maturity. The border rows of all around the plots were harvested first and then the plants from the net plots were harvested and threshed. The grain weight was expressed in $14 \%$ moisture basis (Yoshida et al., 1976) ${ }^{[17]}$ and the yield was expressed in $\mathrm{kg} / \mathrm{ha}$. Similarly, the plot wise straw was sun dried, weighed and the yield was expressed in $\mathrm{kg} \mathrm{ha}^{-1}$.

\section{Result and discussion}

The data on plant height, productive tillers/square meter, total grains/panicle, grain and straw yield were analyzed and presented in Tables 1to5. The pooled mean analysis using three years data on growth and yield characters were statistically analyzed and given below.

\section{Plant height (cm)}

Rice varieties exhibited significant influence on plant height. Norungan variety recorded the maximum plant height of 90.6 $\mathrm{cm}$, followed by Anna (R) 4 rice variety. This was on par with ADT 45 (Table 1). The height of the above varieties varied according to growth habit. Norungan being tall growing habit, the plant height was more compared to other varieties.

Table 1: Effect of varieties and split application of nitrogen and potassium on plant height $(\mathrm{cm})$ (Pooled mean analysis of three years 2014-2017)

\begin{tabular}{|c|c|c|c|c|}
\hline \multicolumn{5}{|c|}{ Plant height at harvesting stage (cm) } \\
\hline Treatments & \multicolumn{5}{|c|}{ Varieties } \\
\hline Split application of N and K & $\mathbf{V}_{\mathbf{1}}$ & $\mathbf{V}_{\mathbf{2}}$ & $\mathbf{V}_{\mathbf{3}}$ & Mean \\
\hline $\mathrm{N}_{1}$ & 75.7 & 72.8 & 88.9 & 79.1 \\
\hline $\mathrm{N}_{2}$ & 76.7 & 73.8 & 89.9 & 80.1 \\
\hline $\mathrm{N}_{3}$ & 78.2 & 75.2 & 91.3 & 81.6 \\
\hline $\mathrm{N}_{4}$ & 79.2 & 76.5 & 92.3 & 82.7 \\
\hline $\mathrm{N}_{5}$ & 80.1 & 77.2 & 93.3 & 83.5 \\
\hline Mean & 77.4 & 74.6 & 90.6 & \\
\hline & $\mathrm{V}$ & $\mathrm{S}$ & $\mathrm{VX} \mathrm{N}$ & \\
\hline $\mathrm{SE} . \mathrm{d}$ & 2.04 & 0.35 & & \\
\hline $\mathrm{CD}(\mathrm{P}=0.05)$ & 5.72 & 0.72 & $\mathrm{NS}$ & \\
\hline
\end{tabular}

Split application of $\mathrm{N}$ and $\mathrm{K}$ levels

The nutrient management practices exhibited significant influences on the plant height. The highest plant height of $83.5 \mathrm{~cm}$ was recorded in the treatment of recommended dose of $\mathrm{p}$ and $1 / 4^{\text {th }}$ dose of $\mathrm{N}$ and $1 / 4^{\text {th }}$ dose of $\mathrm{K}$ as basal and remaining dose of $3 / 4^{\text {th }}$ dose of $\mathrm{N}$ and $3 / 4^{\text {th }}$ dose of $\mathrm{K}$ in 3 splits in $25^{\text {th }}, 45^{\text {th }}$ and $65^{\text {th }}$ DAS $\left(\mathrm{N}_{5}\right)$. This was on par with N4 treatment (Table1). There is no interaction effect between varieties and split application of $\mathrm{N}$ and $\mathrm{K}$ levels. The basal application of entire recommended dose of NPK was recorded in lower plant height $(79.1 \mathrm{~cm})$. Availability of adequate quantity of nitrogen during critical stages of plant growth might have resulted in better growth characters. These results are in accordance with the findings of Bouman et al. 2002) ${ }^{[4]}$. There is no interaction effect between varieties and split application of $\mathrm{N}$ and $\mathrm{K}$ levels.

\section{Yield parameters}

\section{Effect of rice varieties}

The rice varieties have significant influence on productive tillers $/ \mathrm{m}^{2}$.Among the rice varieties, Anna (R) 4 recorded the highest number of productive tillers of 154.8 than other varieties. Norungan recorded the lowest productive tillers of 123.1 .

Table 2: Effect of varieties and split application of nitrogen and potassium on yield attributes (total productive tillers $\mathrm{m}^{2}$ ) (Pooled mean analysis of three years 2014-2017)

\begin{tabular}{|c|c|c|c|c|}
\hline \multicolumn{5}{|c|}{ 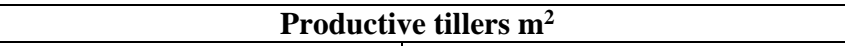 } \\
\hline Treatments & \multicolumn{4}{|c|}{ Varieties } \\
\hline Split application of $\mathrm{N}$ and $\mathrm{K}$ & $V_{1}$ & $\mathbf{V}_{2}$ & $V_{3}$ & Mean \\
\hline $\mathrm{N}_{1}$ & 148.0 & 127.5 & 117.7 & 131.1 \\
\hline $\mathrm{N}_{2}$ & 151.3 & 131.1 & 121.2 & 134.5 \\
\hline $\mathrm{N}_{3}$ & 158.5 & 135.6 & 124.2 & 139.4 \\
\hline $\mathrm{N}_{4}$ & 161.3 & 138.7 & 129.2 & 143.1 \\
\hline $\mathrm{N}_{5}$ & 165.4 & 143.3 & 132.5 & 147.1 \\
\hline Mean & 154.8 & 133.2 & 123.1 & \\
\hline & $\mathrm{V}$ & $\mathrm{S}$ & VXN & \\
\hline SE.d & 7.96 & 1.66 & 2.5 & \\
\hline $\mathrm{CD}(\mathrm{P}=0.05)$ & 22.1 & 3.43 & NS & \\
\hline
\end{tabular}

Split application of $\mathrm{N}$ and $\mathrm{K}$ levels 
The split applications of $\mathrm{N}$ and $\mathrm{K}$ levels have significantly influenced the yield parameters. Among the split application of $\mathrm{N}$ and $\mathrm{K}$ levels, the highest number of productive tillers $147.1 / \mathrm{m}^{2}$ was recorded with the treatment of application of recommended dose of $\mathrm{P}$ and $1 / 4^{\text {th }}$ dose of $\mathrm{N}$ and $1 / 4^{\text {th }}$ dose of $\mathrm{K}$ as basal and remaining quantities of $3 / 4^{\text {th }}$ dose of $\mathrm{N}$ and $3 / 4^{\text {th }}$ dose of $\mathrm{K}$ were applied on $25^{\text {th }}, 45^{\text {th }}$ and $65^{\text {th }}$ DAS in three splits $\left(\mathrm{N}_{5}\right)$. Basal application of recommended dose of NPK in single time of application recorded lower number of productive tillers. Increase in yield attributes might be owing to availability of more nutrients to the crop under different stages than single time application alone. Sathiya and Ramesh (2009) ${ }^{[13]}$ reported that splitting doses of nitrogen in different crop growth stages produced more number of panicles which ultimately responsible for increase in yield. There is no interaction effect between varieties and split application of $\mathrm{N}$ and $\mathrm{K}$ levels.

\section{Total grains/panicle}

\section{Effect of rice varieties}

Among the varieties, Anna (R) 4 rice was recorded the higher number of total grains/panicle (117.7) then followed by ADT 45 rice variety.

\section{Split application of $\mathbf{N}$ and $\mathrm{K}$ levels}

The split applications of $\mathrm{N}$ and $\mathrm{K}$ levels have significantly influenced the yield parameters. Among the split application of $\mathrm{N}$ and $\mathrm{K}$ levels, the highest number of total grains/panicle of 118.8 was recorded with the treatment of application of recommended dose of $\mathrm{P}$ and $1 / 4^{\text {th }}$ dose of $\mathrm{N}$ and $1 / 4^{\text {th }}$ dose of $\mathrm{K}$ as basal and remaining quantities of $3 / 4^{\text {th }}$ dose of $\mathrm{N}$ and $3 / 4^{\text {th }}$ dose of $\mathrm{K}$ were applied on $25^{\text {th }}, 45$ th and $65^{\text {th }}$ DAS in three splits $\left(\mathrm{N}_{5}\right)$. The basal application of entire recommended dose of NPK was recorded the lowest total grains/panicle of 109.6. There is no interaction effect between these varieties and split application of N and K levels. Raju et al., (2014) ${ }^{[10]}$ reported that the application of $\mathrm{N}$ in three equal splits at 20 25 DAE,40-45 DAE and 60-65 DAE recorded higher number of grains/panicle, panicles $/ \mathrm{m}^{2}$, and grains/panicle.

Table 3: Effect of varieties and split application of nitrogen and potassium on yield attributes (Total grains panicle ${ }^{-1}$ ) (Pooled mean analysis of three years 2014-2017)

\begin{tabular}{|c|c|c|c|c|}
\hline \multicolumn{5}{|c|}{ Total grains/panicle } \\
\hline Treatments & \multicolumn{4}{|c|}{ Varieties } \\
\hline Split application of N and K & $\mathbf{V}_{\mathbf{1}}$ & $\mathbf{V}_{\mathbf{2}}$ & $\mathbf{V}_{\mathbf{3}}$ & Mean \\
\hline $\mathrm{N}_{1}$ & 114.8 & 112.0 & 101.8 & 109.6 \\
\hline $\mathrm{N}_{2}$ & 116.3 & 114.6 & 104.4 & 111.8 \\
\hline $\mathrm{N}_{3}$ & 118.6 & 115.8 & 108.5 & 114.3 \\
\hline $\mathrm{N}_{4}$ & 120.9 & 118.1 & 110.3 & 116.4 \\
\hline $\mathrm{N}_{5}$ & 123.1 & 120.4 & 113.0 & 118.8 \\
\hline Mean & 117.7 & 115.3 & 106.2 & \\
\hline & $\mathrm{V}$ & $\mathrm{S}$ & $\mathrm{VX} \mathrm{N}$ & \\
\hline $\mathrm{SE} . d$ & 1.4 & 0.85 & 7.3 & \\
\hline $\mathrm{CD}(\mathrm{P}=0.05)$ & 3.1 & 1.75 & $\mathrm{NS}$ & \\
\hline
\end{tabular}

\section{Grain yield (kg/ha)}

\section{Effect of rice varieties on grain yield}

The varieties had significant influence on grain yield. The rice variety Anna (R) 4 registered higher grain yield (2298 kg ha$\left.{ }^{1}\right)$. This was on par with ADT 45. Norungan recorded the lowest grain yield of $2001 \mathrm{~kg} \mathrm{ha}^{-1}$.
Table 4: Effect of varieties and split application of nitrogen and potassium on grain yield (Pooled mean analysis of three years 20142017)

\begin{tabular}{|c|c|c|c|c|}
\hline \multicolumn{5}{|c|}{ Grain yield (kg/ha) } \\
\hline Treatments & \multicolumn{4}{|c|}{ Varieties } \\
\hline Split application of N and K & $\mathbf{V}_{\mathbf{1}}$ & $\mathbf{V}_{\mathbf{2}}$ & $\mathbf{V}_{\mathbf{3}}$ & Mean \\
\hline $\mathrm{N}_{1}$ & 2240 & 1794 & 1773 & 1936 \\
\hline $\mathrm{N}_{2}$ & 2515 & 1996 & 2045 & 2185 \\
\hline $\mathrm{N}_{3}$ & 2700 & 2277 & 2233 & 2403 \\
\hline $\mathrm{N}_{4}$ & 2849 & 2429 & 2343 & 2540 \\
\hline $\mathrm{N}_{5}$ & 3017 & 2526 & 2413 & 2652 \\
\hline Mean & 2298 & 2029 & 2001 & \\
\hline & $\mathrm{V}$ & $\mathrm{S}$ & $\mathrm{V} \mathrm{X}$ & \\
\hline $\mathrm{SE} . \mathrm{d}$ & 128 & 60 & 159 & \\
\hline $\mathrm{CD}(\mathrm{P}=0.05)$ & 286 & 124 & $\mathrm{NS}$ & \\
\hline
\end{tabular}

\section{Effect of split application of $\mathbf{N}$ and $\mathrm{K}$ levels}

Application of $\mathrm{N}$ and $\mathrm{K}$ of $\mathrm{P}$ and $1 / 4^{\text {th }}$ dose of $\mathrm{N}$ and $1 / 4^{\text {th }}$ dose of $\mathrm{K}$ as basal and topdressing of $3 / 4^{\text {th }}$ dose of $\mathrm{N}$ and $3 / 4^{\text {th }}$ dose of $\mathrm{K}$ in 3 splits on $25^{\text {th }}, 45^{\text {th }}$ and $65^{\text {th }}$ DAS (N5)recorded the highest grain yield of $2652 \mathrm{~kg} / \mathrm{ha}$. This was on par with N4 treatment. Basal application of recommended dose of NPK recorded in lower grain yield of $1936 \mathrm{~kg} / \mathrm{ha}$. Shaiful et al. (2009) ${ }^{[14]}$ observed that effect of split application of $\mathrm{N}$ fertilizer on grain yield. The grain yield was the lowest when the quantity of $\mathrm{N}$ supply was restricted in the early stages and increased after panicle initiation (Akita 1989 and Vijayalakshmi et al., 1992) ${ }^{[2,15]}$. The trend of grain yield for the $\mathrm{N}$ levels and split application was similar in both dry season and SWM seasons, but with varied magnitude. There is no significant effect between these varieties and split application of $\mathrm{N}$ and $\mathrm{K}$ levels. The efficient Nitrogen and Potassium uptake by rice plant results in better growth and development when applied at maximum tillering stage (25 DAT) and at Panicle initiation stage (45 DAT). Similar results were reported by Sarkar et al., (1995) ${ }^{[12]}$ and Raju et al., (1999) ${ }^{[9]}$ and Samrathlal et al., (2003) ${ }^{[11]}$.

\section{Effect of rice varieties on straw yield}

Rice varieties have significant effect on straw yield. Norungan (local) rice variety recorded the highest straw yield of $4021 \mathrm{kgha}^{-1}$ then followed by Anna (R) 4 rice variety. The increase may be due to tall nature of Norungan variety.

Table 5: Effect of varieties and split application of nitrogen and potassium on straw yield (Pooled mean analysis of three years 20142017)

\begin{tabular}{|c|c|c|c|c|}
\hline \multicolumn{5}{|c|}{ Straw yield (kg/ha) } \\
\hline Treatments & \multicolumn{4}{c|}{ Varieties } \\
\hline Split application of N and K & V1 & V2 & V3 & Mean \\
\hline N1 & 3387 & 3093 & 3784 & 3421 \\
\hline N2 & 3627 & 3308 & 4055 & 3663 \\
\hline N3 & 3814 & 3444 & 3995 & 3751 \\
\hline N4 & 3960 & 3530 & 4250 & 3913 \\
\hline N5 & 4219 & 3692 & 4255 & 4055 \\
\hline Mean & 3697 & 3344 & 4021 & \\
\hline SE.d & V & S & V X N & \\
\hline CD(P=0.05) & 159 & 185 & 486 & \\
\hline
\end{tabular}

\section{Effect of split application of $\mathbf{N}$ and $\mathrm{K}$ levels}

Among the split application of $\mathrm{N}$ and $\mathrm{K}$ levels, The highest straw yield of $4055 \mathrm{kgha}^{-1}$ was recorded with the treatment of application of recommended dose of $\mathrm{P}$ and $1 / 4^{\text {th }}$ dose of $\mathrm{N}$ and $1 / 4^{\text {th }}$ dose of $\mathrm{K}$ as basal and remaining quantities of $3 / 4^{\text {th }}$ dose of $\mathrm{N}$ and $3 / 4^{\text {th }}$ dose of $\mathrm{K}$ as on $25^{\text {th }}, 45^{\text {th }}$ and $65^{\text {th }}$ DAS in three 
splits $\left(\mathrm{N}_{5}\right)$. This was on par with $\mathrm{N}_{4}$ and $\mathrm{N}_{3}$ treatments. These results confirm the findings of Gunri et al., (2004) ${ }^{[5]}$. There is no interaction effect between varieties and split application of $\mathrm{N}$ and $\mathrm{K}$ levels.

\section{Economic evaluation of varieties and split application of $\mathbf{N}$ and $K$}

The cost of cultivation for the above system is ranged from Rs. 15,000 to $15,500 \mathrm{ha}^{-1}$ under varying situations. The short duration rice variety Anna (R) 4 is suitable for semi-dry rice cultivation with application of recommended dose of $\mathrm{P}$ with $1 / 4^{\text {th }}$ dose of $\mathrm{N}$ and $1 / 4^{\text {th }}$ dose of $\mathrm{K}$ as basal and remaining dose of top dressing of $3 / 4^{\text {th }}$ dose of $\mathrm{N}$ and $\mathrm{K}$ in 3 splits on $25^{\text {th }}, 45^{\text {th }}$ and $65^{\text {th }}$ DAS which recorded the good performance of growth and yield which ultimately increase the net return of Rs. 17173 ha $^{-1}$ and the B: C ratio of 2.11 .

Table 6: Effect of varieties and split application of nitrogen and potassium on Economic evaluation of semi-dry rice cultivation (Pooled mean analysis)

\begin{tabular}{|c|c|c|c|c|c|}
\hline S. No & Treatment & Cost of cultivation (Rs/ha) & Gross return (Rs/ha) & Net return (Rs/ha) & B: C ratio (Rs/ha) \\
\hline 1. & V1N1 & 15000 & 21493 & 6493 & 1.43 \\
\hline 2. & V1N2 & 15250 & 24087 & 8837 & 1.58 \\
\hline 3. & V1N3 & 15250 & 28673 & 13423 & 1.88 \\
\hline 4. & V1N4 & 15500 & 30030 & 14530 & 1.94 \\
\hline 5. & V1N5 & 15500 & 32673 & 17173 & 2.11 \\
\hline 6 & V2N1 & 15000 & 17503 & 2503 & 1.17 \\
\hline 7. & V2N2 & 15250 & 22730 & 7480 & 1.49 \\
\hline 8. & V2N3 & 15250 & 24173 & 8923 & 1.59 \\
\hline 9. & V2N4 & 15500 & 25770 & 10270 & 1.66 \\
\hline 10. & V2N5 & 15500 & 27340 & 11840 & 1.76 \\
\hline 11. & V3N1 & 15000 & 20673 & 5673 & 1.38 \\
\hline 12. & V3N2 & 15250 & 23547 & 8297 & 1.54 \\
\hline 13. & V3N3 & 15250 & 26063 & 10813 & 1.71 \\
\hline 14. & V3N4 & 15500 & 27320 & 11820 & 1.76 \\
\hline 15. & V3N5 & 15500 & 28407 & 12907 & 1.83 \\
\hline
\end{tabular}

\section{Conclusion}

From the investigation, it can be concluded that the short duration rice variety Anna $(\mathrm{R}) 4$ is suitable for semi-dry rice cultivation under drought conditions of Ramanathapuram district. Application of entire recommended dose of $\mathrm{P}$ with $1 / 4^{\text {th }}$ dose of $1 / 4^{\text {th }}$ dose of $\mathrm{N}$ and $1 / 4^{\text {th }}$ dose of $\mathrm{K}$ as basal application of remaining dose of $\mathrm{N}$ and $\mathrm{K}$ in three splits on vegetative, active tillering and panicle initiation stages has recorded higher grain yield.

\section{References}

1. Ahmed S, Ranjha AM, Waheed T. Long term effect of ammonium chloride Application in comparison with conventional nitrogen sources for rice production. JAPS. 1994; 4(1-2):1-3.

2. Akita S. Improving yield potential in tropical rice. In: Progress in irrigated rice research. Procedings of Internstional Rice Research Conference, Hangzhou, China, 1989, 41-73.

3. Bouman BAM, Lampayan RM. Aerobic rice $1 \& 2$. Int Rice Research Institute Philippines, 2009.

4. Bouman BAM, Xiaoguang Y, Huaqui W, Zhiming W, Junfang Z, Changgui W et al. Aerobic rice (Han Dao): A new way growingrice in water short areas. In: Proceedings of the $12^{\text {th }}$ International Soil Conservation organization Conference. May 26-31. Beijing, China. Tsinghua University, 2002, 175-181.

5. Gunri S, Pal K, Choudhury A. Effect of integrated nitrogen application and spacing on yield of rice (oryza sativa) in foot hill soils of West Bengal. Indian $\mathbf{J}$ Agronomy. 2004; 49(4):248-250.

6. Hasegawa T, Koroda Y, Seligman NG, Horie T. Response to spikelet number of plant nitrogen concentration and dry weight in Paddy. Agron. J. 1994; 86:673-676.

7. Kumar V, Ladha JK. Direct seeded rice: Recent development and future research needs. Advances in Agronomy. 2011; 111:297-13.

8. Panse VG, Sukhatme PV. Statistical methods for agricultural workers. ICAR New Delhi. Prasad, R. 2011 Aerobic rice systems. Advances in Agronomy. 1967; 111:207-47.

9. Raju RAK, Reddy S, Reddy MN. Potassium fertilization in rice (Oryza sativa L.,) on vertisols of Godavari flood plains Indian J of Agron. 1999; 44(1):99-101.

10. Raju SKJ, Bindhu S, Girijadevi L. Nitrogen availability and uptake as influenced by time of application and $\mathrm{N}$ source in semi-dry rice. J of Crop and Weed. 2014; 0(2):295-302.

11. Samrathlal Surendra M, Shivay YS. Response of hybrid rice (Oryza sativa) to nitrogen and potassium application in sandy clay - loam soils. Indian J of Agri. Sci. 2003; 73(1):8-11.

12. Sarkar RK, Bhattacharya AM, Chakraborty SR, Satpathy C. Response of rice to $\mathrm{N}$ and $\mathrm{K}$ application in Gangetic alluvial soils of West Bengal. J Potassium Res. 1995; 11(3):297-301.

13. Sathiya K, Ramesh T. Effect of split application of nitrogen on growth andyield of aerobic rice. Asian J Exp. Sci. 2009; 23(1):303-306.

14. Shaiful Islama, Hasanuzzaman Rokonuzzamanc B, Nahard K. Effect of split application of nitrogen fertilizer on morpho physiological parameters of rice genotypes International J of Plant Production, 2009, 3(1).

15. Vijayalaksmi C, Radhakrishnan R, Nagarajan $N$, Natarajamoorthy K. Effective management of Nitrogen 
for increased productivity in Rice. Madras Agricultural J. 1992; 79:158-162.

16. Yoshida S, Forno DA, Cock JHand, Gomez KA. Laboratory Manual for physiological studies of Rice. IRRI, LosBanos, Philippines, 1976, 83.

17. Yoshida H, Horie T, Shiraiwa T. A model explaining genotypic and environmental variation of rice spikelet number per unit area measured by cross -locational experiments in Asia. Field Crops Res. 2006; 97:3378343. 